\title{
HIGH RISK OF FAILED SKIN GRAFT ON MAJOR BURN PATIENTS WITH COMPLICATION OF HYPERNATREMIA
}

\author{
Lynda Hariani ${ }^{*}$, Agus Santoso Budi ${ }^{1}$, Ephora Christina Wulandari² \\ ${ }^{1}$ Staff of Department of Plastic Reconstructive and Aesthetic Surgery, Faculty of Medicine, Universitas Airlangga, \\ Surabaya, Indonesia/Dr. Soetomo General Academic Hospital, Surabaya, Indonesia \\ ${ }^{2}$ Department of Plastic Reconstructive and Aesthetic Surgery, Faculty of Medicine, Universitas Airlangga/Dr. \\ Soetomo General Academic Hospital Surabaya, Indonesia
}

\section{ABSTRACT}

The rate of failed skin graft in Dr. Soetomo General Academic Hospital Surabaya was around $26 \%$ of the cases, and it became a concern, because skin graft was the main procedure to close large burn wound. Many problems might affect this event; one of them was electrolyte imbalance. Hypernatremia was seen in major burn patients. This condition caused the disruption of wound healing process of skin graft. A cross sectional study of patients with burns admitted to the Burn Centre of Dr. Soetomo Hospital between January 2014 and December 2018 were evaluated. 143 subjects were involved in this study. Hypernatremia was found in $16 \%$ of all subjects (23 subjects), $19 \%$ with hypernatremia (28 subjects) and majority of it, $65 \%$ with normonatremia (92 subjects). This study found that the risk of failed skin graft was higher on hypernatremia than normonatremia subjects. This risk was higher if the skin graft procedure took more than $10 \%$.

Keywords: hypernatremia; skin graft; major burn patients

\section{ABSTRAK}

Tingkat kegagalan skin graft di Rumah Sakit Dr. Soetomo Surabaya mencapai 26\%, dan hal ini mengkhawatirkan, karena skin graft merupakan pilihan prosedur utama untuk penutupan luka bakar luas. Risiko kegagalan meliputi banyak hal, salah satunya adalah ketidakseimbangan elektrolit. Hipernatremia merupakan komplikasi yang umum pada pasien luka bakar berat yang dapat mengganggu proses penyembuhan skin graft. Penelitian cross sectional dilakukan pada pasien luka bakar yang dirawat di Unit Luka Bakar RS Dr. Soetomo pada Januari 2014 hingga Desember 2018. Ada 143 pasien yang diteliti. Hiponatremia adalah komplikasi yang diderita oleh $16 \%$ dari total pasien (23 pasien), 19\% dari total pasien menderita komplikasi hiponatremia (28 pasien) dan sisanya, 65\% dari total pasien, menderita komplikasi normonatremia (92 pasien). Studi ini menunjukkan bahwa pasien luka bakar dengan komplikasi hipernatremia memiliki risiko kegagalan skin graft lebih tinggi dibanding pasien normonatremia. Risiko kegagalan ini akan bertambah besar pada prosedur skin graft dengan luas lebih dari $10 \%$.

Kata kunci: hypernatremia; skin graft; pasien luka bakar berat

Correspondence: Lynda Hariani, Staff of Department of Plastic Reconstructive and Aesthetic Surgery, Faculty of Medicine, Universitas Airlangga, Surabaya, Indonesia/Dr. Soetomo General Academic Hospital, Surabaya, Indonesia. Email: lynda.hariani@fk.unair.ac.id

pISSN:2355-8393 • eISSN: 2599-056x • doi: 10.20473/fmi.v57i2.17864

- Fol Med Indones. 2021;57:166-169 • Received 11 Feb 2020 • Accepted 14 May 2020

- Open access under CC-BY-NC-SA license • Available at https://e-journal.unair.ac.id/FMI/ 


\section{INTRODUCTION}

Skin graft remains as main choice to close burn wound especially large burn wound on severe burn patients (Rowan et al 2015, Jeschke et al 2020). This is a routine procedure but there are various risks than can cause the failure. From data from 2014-2018, failure rate of skin graft in Dr. Soetomo General Academic Surabaya reached 26\% (Saputro et al 2020). This was such a high number that showed the dynamic of clinical conditions of burn that made it hard to assure the success of skin graft.

Electrolyte imbalance is one of risk that affects the success rate of skin graft (Atmadja \& Sudjatmiko 2012, Kurianto \& Arianti 2018). Hypernatremia is increasing the risk of apoptosis and can deepen the burn (Namdar et al 2010, Lam \& Minh 2018). Thus, it is believed that hypernatremia can also influence skin graft healing process. This study was to explore the hypothesis that hypernatremia in burn patients could affect success rate of skin graft.

\section{MATERIALS AND METHODS}

This study used cross-sectional analytic descriptive design with retrospective secondary data. Take of the skin graft was evaluated by clinical appearance; the skin graft appeared pinkish that showed a good vascularization. A success skin graft procedure showed "take" when the skin graft was $>=90 \%$, while "take" skin graft $<90 \%$ needed further procedures, such as second stage operation or wound treatment that was considered failed.

The samples of this study were all of burn patients that underwent skin graft procedure in Dr. Soetomo General Academic Hospital Surabaya on period of January 2014 to December 2018 with a total of 143 patients. Burn patients with hypernatremia that underwent skin graft procedure were included. The procedure was done by third year of residency or above. On the other hand, burn patients that had complications, such as anemia $(\mathrm{Hb}<11 \mathrm{gr} / \mathrm{dL})$, hypoalbuminemia $(\mathrm{Alb}<3 \mathrm{gr} / \mathrm{dL}$ ) or sepsis were excluded.

\section{RESULTS}

From research result, most of the patients were male. The number of male patients was 99 patients $(69 \%)$ and 44 female patients $(31 \%)$. The biggest cause of burn patients was fire (93 cases). It was followed by electric burn (20 cases), scald (12 cases), hot oil (8 cases), chemical agent (6 cases), steam ( 3 cases) and the least blast injury (1 cases). The skin graft procedure mainly did for less than $10 \%$, which were 110 cases. The rest were more than $10 \%$ or 33 cases. The total patients with hypernatremia were 23 patients, and 92 patients were mostly normonatremia.

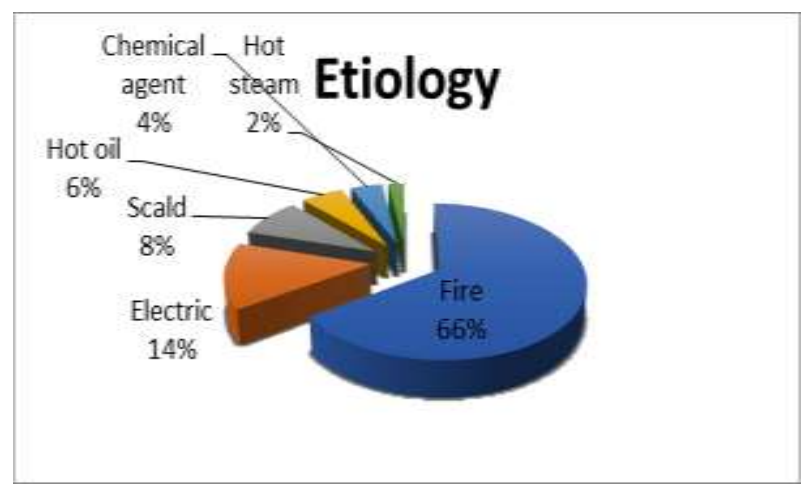

Figure 1. Figure 1. Etiology of burn

\section{Skin Graft Procedure}

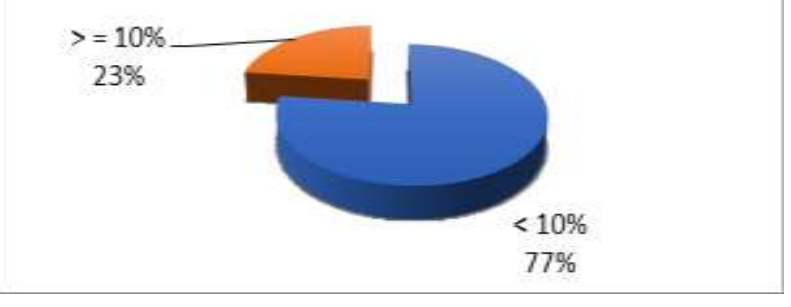

Figure 2. Skin graft procedure

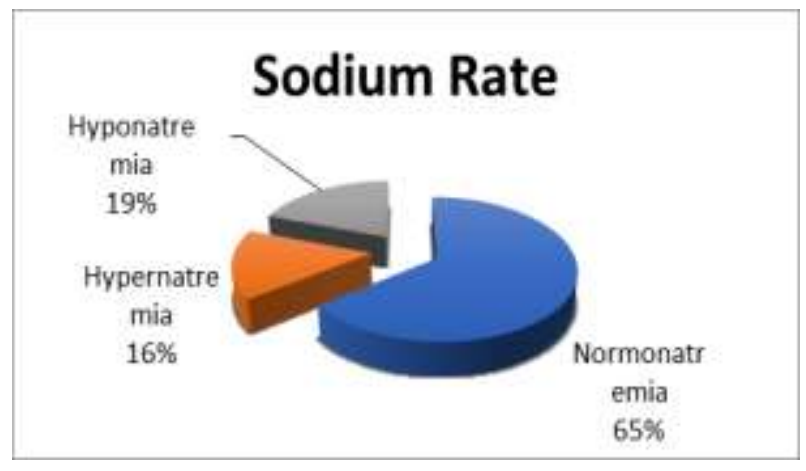

Figure 3. Sodium rate

In this study, hypernatremia patients had greater chance to failed skin graft, which was 6.06 times than normonatremia patients. From more than $10 \%$ skin graft procedure, hypernatremia patients had bigger chance to failed skin graft, which was 16.5 times than normonatremia patients. From less than $10 \%$ skin graft procedure, hypernatremia patients had a bigger chance 
to failed skin graft, which was 6.06 times than normonatremia patients.

Table 1. Data analysis

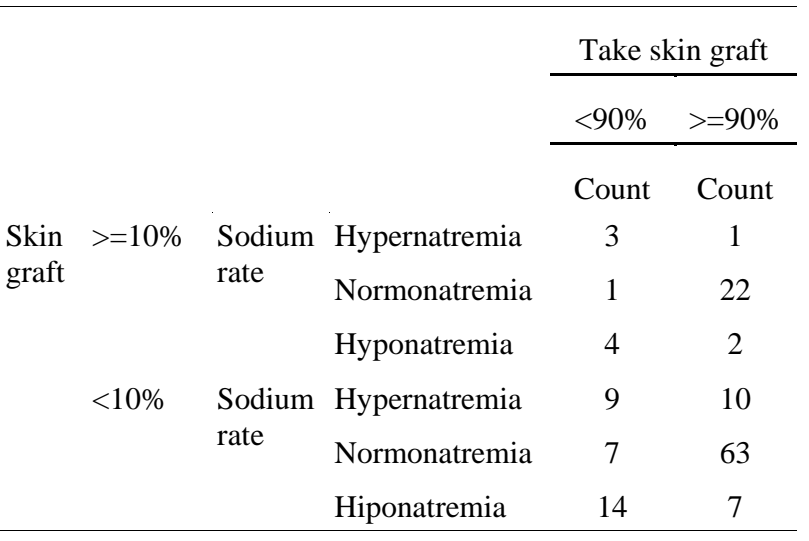

\section{DISCUSSION}

From this research, it showed that hypernatremia could be one of the risks that decreased the success rate of skin graft on burn patients (Bataille et al 2014). Hypernatremia showed the large movement of fluid through membrane that caused systemic dehydration (Nur et al 2014); this caused decreasing of tissue perfusion, because there was a systemic activation of Na-K pumps that used a large amount of energy, and this led to decreasing number of energies for healing process. All of them caused cell apoptosis.

The cell apoptosis was also caused by protein produced by the heat of burn (Papaliagkas et al 2007, Nielson et al 2017). Hypernatremia condition was signed of osmotic injury that could accelerate the apoptosis process of cell (Elmore 2007, Xiong et al 2019). Without sufficient perfusion of recipient bed, revascularization was not achieved, thus caused disrupt of healing process of skin graft.

This retrospective study only included small sample size of burn patients. The total number patients with hypernatremia were only 22 patients. Different surgeons did the procedures of skin graft, and this could also affect the success rate of skin graft.

\section{CONCLUSION}

There were various risks that could cause the failure of skin graft on major burn patients, one of them was hypernatremia. Major burn patients with complication hypernatremia increased the risk of failed skin graft than normonatremia patients. The bigger percentage of skin graft procedure resulted the bigger risk to fail.

\section{REFERENCES}

Atmadja TM, Sudjatmiko G (2012). Management of patient with closed degloving in the pelvic region: A case series. Jurnal Plastik Rekonstruksi 1, 472-477.

Bataille S, Baralla C, Torro D, et al (2014). Undercorrection of hypernatremia is frequent and associated with mortality. BMC Nephrol 15, 1-9.

Elmore S (2007). Apoptosis: A review of programmed cell death. Toxicol Pathol 35, 495-516.

Jeschke MG, van Baar ME, Choudhry MA, et al (2020). Burn injury. Nat Rev Dis Primers 6, 1-2.

Kurianto E, Arianti (2018). Status cairan pada pasien pasca pembedahan di RS PKU Muhammadiyah Gamping. Indonesian Journal of Nursing Practices 2, 68-76.

Lam NN, Minh NTN (2018). Risk factors and outcome of Hypernatremia amongst severe adult burn patients. Ann Burns Fire Disasters 31, 271-277.

Namdar T, Siemers F, Stollwerck PL, et al (2010). Increased mortality in hypernatremic burned patients. Ger Med Sci 8, 1-6.

Nielson CB, Duethman NC, Howard JM, et al (2017). Burns: Pathophysiology of systemic complications and current management. J Burn Care Res 38, e469e481.

Nur S, Khan Y, Nur S, et al (2014). Hypernatremia: Correction rate and hemodialysis. Case Reports in Medicine 2014, 1-5.

Papaliagkas V, Anogianaki A, Anogianakis G, et al (2007). The proteins and the mechanisms of apoptosis: A mini-review of the fundamentals. Hippokratia 11, 108-113.

Rowan MP, Cancio LC, Elster EA, et al (2015). Burn wound healing and treatment: Review and advancements. Critical Care 19, 1-12.

Saputro ID, Budi AS, Noverta DA (2020). Factors that affecting the skin necrotic due to extravasation injury and modality theraphy at pediatric inpatient ward dr. Soetomo Hospital Surabaya (Januari - Desember 2019). Jurnal Rekonstruksi dan Estetik 6, 28-34.

Xiong S, Sun HJ, Cao L, et al (2019). Stimulation of $\mathrm{Na}^{+} / \mathrm{K}^{+}$-ATPase with an antibody against its $4^{\text {th }}$ extracellular region attenuates angiotensin II-induced $\mathrm{H} 9 \mathrm{c} 2$ cardiomyocyte hypertrophy via an 
AMPK/SIRT3/PPAR $\gamma$ signaling pathway. Oxidative Medicine and Cellular Longevity 2019, 1-17. 